\title{
Experimental Organism Basal Cell Carcinoma
}

National Cancer Institute

\section{Source}

National Cancer Institute. Experimental Organism Basal Cell Carcinoma. NCI Thesaurus.

Code C111199.

A malignant epithelial neoplasm arising from basal cells. (SEND) 